\title{
Bi-facial Open-Space Photovoltaic Systems versus Conventional Systems using Mono-facial Modules
}

\section{A Technical and Economic Comparison}

\author{
Marcus Schmidt ${ }^{1,2}$, Martin Hinneburg ${ }^{2}$, Lutz B. Giese ${ }^{3}$ \\ ${ }^{1}$ Technische Hochschule Wildau (Graduate), Germany \\ 2 SUNfarming GmbH Erkner, Germany \\ 3 Technische Hochschule Wildau, Germany
}

\begin{abstract}
As part of a scientific work within the solar company Sunfarming $\mathrm{GmbH}$, the aim was to find out whether bi-facial modules on open spaces deliver better results economically than conventional mono-facial solar modules. In this context, an already installed $750 \mathrm{~kW}_{\mathrm{p}}$ PV system with mono-facial solar modules was compared directly with a structurally identical PV system with bi-facial modules, which, however, does not exist in practice but was only simulated with PV software. The second part of the investigation includes the comparison of four different assembly systems or elevation variants in order to determine the system with the best relationship between system yield and costs.
\end{abstract}

The final result of the first investigation showed that the use of bi-facial modules reduced the specific costs per kWh by approximately $5 \%$. In order to improve this effect, the use of compact assembly systems is recommended, e.g. five rows of modules per table with horizontal alignment.

Keywords: Bi-facial photovoltaics, open-space PV systems, Renewable Energy Sources

\section{Introduction}

For many years, photovoltaics have been one of the most important players in renewable power generation in Germany. The PV modules have been optimized in terms of production and quality, especially in the last 10 years, which at the same time increased customer demands, prices have fallen and the degree of efficiency depending on the design has already reached over $20 \%$. With the aim of placing as much power as possible in a small area, the trend of bi-facial modules developed on the market in 2018/2019. The technology is able to convert solar radiation into electrical energy on both the front and rear of the module. According to the suppliers and manufacturers, additional energy yields of 5-30\% compared to mono-facial modules are possible depending on the orientation, inclination and shading [1].

In this context, the question arises to what extent the bi-facial standard modules compare to mono-facial modules in terms of additional power and whether these can generally replace the conventional modules in open spaces. For this consideration, the actual costs and energy yields of a current open-space system were examined and compared with the costs and yields of a simulated system with bi-facial modules. 


\section{PV Open Space Systems}

A ground-mounted PV system basically consists of the following main components:

- Mounting system / substructure

- Solar modules

- Generator connection boxes

- Inverter

- Transformer and transfer station

The mounting system is used to hold and align modules (Figure 1). The modules are

inclined to a certain angle $\left(15^{\circ}-30^{\circ}\right)$ with the aid of the frames, while this is already guaranteed

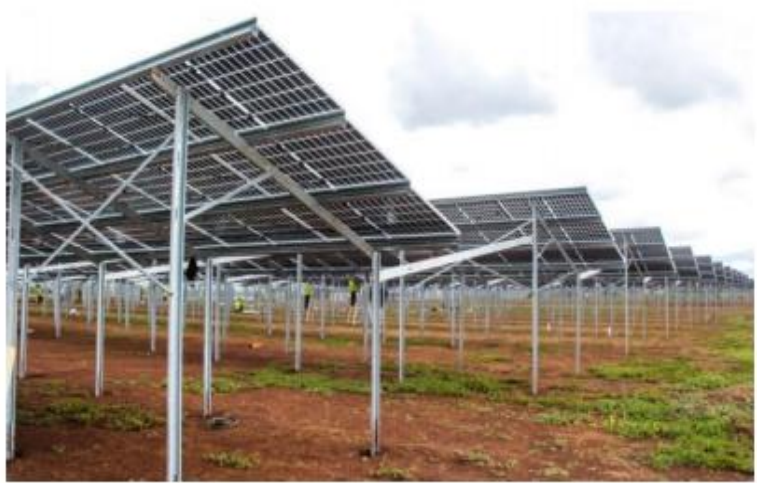

Figure 1. PV system with bi-facial modules. by the roof inclination in roof systems. The more module rows a table has, the lower the inclination must be selected in order to minimize the effect of wind loads. The mounting system is one of the most important factors influencing the effectiveness of the PV system [2].

A conventional mono-facial solar module usually consists of several crystalline solar cells with silicon as the starting material. The solar cells form the heart of a PV system, as the actual photovoltaic effect takes place in these or convert the energy of the photons into electricity. In practice, mainly polycrystalline (light blue appearance) and monocrystalline (dark blue appearance) are used, which differ only in terms of the type of production and the degree of efficiency. While polycrystalline solar modules have an efficiency of $13-17 \%$, monocrystalline modules can have an efficiency of more than $20 \%$, but this is associated with higher costs. In a PV system, the solar modules are connected in series, creating socalled strings that are then led to the generator junction box [3].

The nominal output of a solar module is specified in kilowatt-peak $\left(\mathrm{kW}_{\mathrm{p}}\right)$ and indicates the maximum output of the module, which is also optimized with half-cell technology (Figure 2). If the cells are halved after production, the peak performance can be improved by $2-3 \%$ according to the Fraunhofer Institute for Solar Energy Systems, since the electrical resistance and thus the
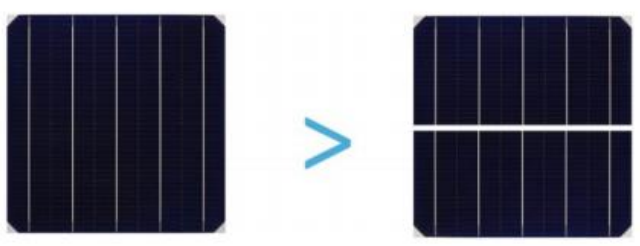

Figure 2. Half-cell technology [4]. energy losses are reduced within the cell connectors [4]

The generator junction boxes have the task of bringing the individual solar cables or strings together and, if necessary, of separating the load from the rest of the system by means of a switch disconnector (e.g. for maintenance work). By merging the strings, cable runs and costs can be saved [2].

The solar generator generates direct current and can therefore not feed into the power grid with alternating current. Therefore, all PV modules must be connected to one or more inverters depending on the generator power. This converts the direct current (DC) into alternating current (AC). In addition to the conversion, the inverters also perform the following tasks [3]:

- Performance optimization

- Plant monitoring

- Power feed-in 
Performance optimization: The inverter detects the point of maximum power (MPP = Maximum Power Point) per module string. This point is different at any time depending on the irradiance, shading and module temperature, which is why the MPP is constantly searched for and tracked (MPP tracking) [5].

Plant monitoring: Thanks to the independent operation, inverters can switch to standby mode when the voltage is too low in order to save energy and switch on again when there is sufficient incidence of light. They can also automatically disconnect themselves from the network in the event of network faults or failures using a disconnection device. With the help of a communication interface, the inverters and thus the yields of the PV system can be remotely monitored at any time, e.g. to quickly identify any loss of yield [6].

Power feed-in: After a successful conversion, the electricity is fed into the corresponding electricity network. While this process takes place in small PV systems (e.g. $5 \mathrm{~kW}_{\mathrm{p}}$ ) via the house connection with $230 \mathrm{~V}$, larger systems (e.g. $750 \mathrm{~kW}$ open-space systems) feed into the medium-voltage network between $1 \mathrm{kV}$ and $35 \mathrm{kV}$ via the transformer or the transfer station [2].

The transformer is connected to the PV generator via the inverter and transforms the output voltage of the inverter to the required medium-voltage level. In addition, with the help of a switchgear within the station, it is possible to disconnect the transformer from the power grid [2].

However, the energy from the PV system is fed into the public grid with the help of the transfer station. This also takes over the counting of the energy generated by the generator and at the same time forms the property boundary of the PV operator and the responsible network operator [7].

\section{Bi-facial Modules PV Open Space System}

In contrast to the mono-facial cell, the bi-facial solar cell can convert the solar radiation on the front as well as on the back into electricity. However, these are not two separate areas, but simply the same item. The bi-facial PERC cell (PERC = Passivated Emitter Rear Cell) is characterized by its dielectric layer (dielectric $=$ non-conductive). The illustration in Figure 3 shows both a conventional solar cell and a PERC cell. The standard cell (left) has a fullsurface aluminum metallization on the back, which serves as a conductive contact for the cell. The PERC technology, on the other hand, involves the creation of a dielectric layer that has several small holes with the help of a laser. This means that the silicon wafers only have contact with the aluminum metallization through the tiny holes [1].

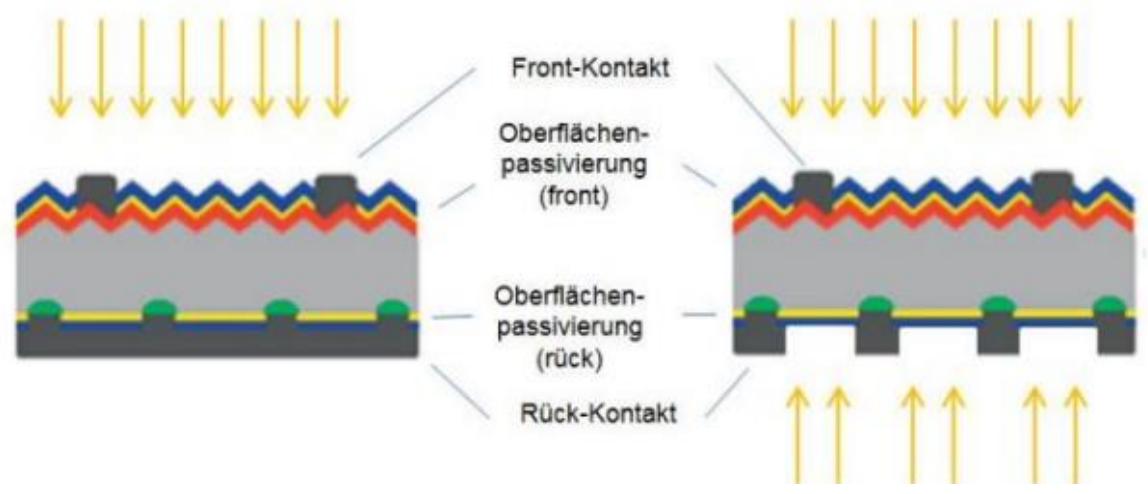

Figure 3. PERC cell technology [8] (in German).

By modifying the back of the cell, the radiation can also be received from the back. In order to fulfill this function, there must also be a transparent back [8]. 
The back is not symmetrical with the front and for this reason can only partially absorb the radiation as efficiently. The ratio between back and front performance is called the bifacial factor and is approximately $70 \%$ under standard test conditions [1].

In addition, there are the following influencing factors that influence the rear side yield of bi-facial modules:

The reflection factor (albedo) is a percentage of the reflection radiation that hits the back of the module and depends on the color and nature of the surface. While light colors have an albedo value of approximately $60-90 \%$ (e.g. snow), grass, for example, guarantees a value of approximately $23 \%$ [1].

The higher the angle of installation, the more diffuse radiation can reach the rear, and the same applies to the installation height of the module tables [1].

The row spacing between the module tables also has an influence on the radiation behind the modules. At short distances, the horizon is narrowed down, so that the diffuse radiation decreases. Self-shading can also occur at low positions in the sun if a module table is too close to the rear one [1].

The last influencing factor is the shading from the solar cables and the mounting system. The profiles of the mounting system should therefore not cover the rear of the bi-facial modules [1].

\section{Economics of Bi-facial PV Systems}

\section{Economic Comparison of Two 750 kW $\mathrm{p}$ PV Systems}

A $750 \mathrm{~kW}_{\mathrm{p}}$ PV system that had already been built by SUNfarming $\mathrm{GmbH}$ was used as the basis for the investigation, and its investment costs were compared with the annual energy yields in order to calculate the specific costs in $€ / \mathrm{kWh}$. In the study, these specific costs should represent a measure of the profitability of a PV system.

With the help of the simulation software PV-Sol, it was then possible to simulate the same PV system with the same technical configurations that instead contains bi-facial solar modules. For the simulation system, the theoretical investment costs and yield data were also put in relation and the specific costs were calculated. According to the comparison, the specific costs when using bi-facial modules decreased by $3.17 \%$. However, it should be noted here that it is not certain whether the simulation software can calculate the actually possible energy yield through the rear. An additional energy yield of approximately $5 \%$ was output in the simulation, which can therefore differ slightly from reality.

\section{Economic Comparison of Different System Concepts}

In the second part of the investigation, the standard assembly system used was compared economically with four other elevation concepts. An area of approximately 4 hectares was used as the basis, which was covered by the concepts below in full simulation.

The fundamental data set of the installation concepts and their technical configuration is shown in Table 1.

Table 1. Comparison of the system concepts [own illustration].

\begin{tabular}{|l|l|l|l|l|l|}
\hline Concepts/ Reference & Concept 1 & Concept 2 & Reference & Concept 3 & Concept 4 \\
\hline Orientation of modules & Vertical & Horizontal & horizontal & horizontal & horizontal \\
\hline Module rows per table & 2 & 3 & 4 & 5 & 6 \\
\hline Installation angle & $30^{\circ}$ & $30^{\circ}$ & $25^{\circ}$ & $20^{\circ}$ & $15^{\circ}$ \\
\hline Elevation (in m) & 0.6 & 0.6 & 0.6 & 0.6 & 0.6 \\
\hline Row spacing (in $\mathrm{m}$ ) & 3 & 3 & 3 & 3 & 3 \\
\hline
\end{tabular}


In Figure 4 sketches of the configurations can be seen.

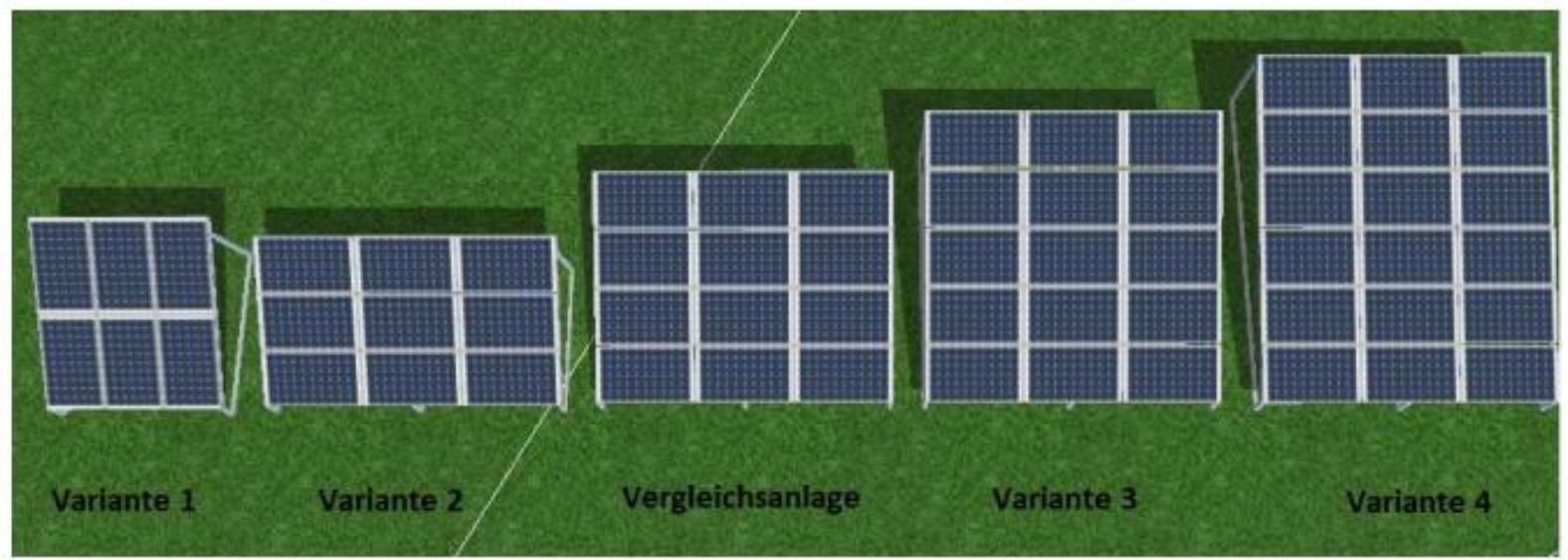

Figure 4. System concepts 1 to 4 and reference [own illustration; in German].

During the simulations of the individual concepts, it turns out that the space utilization increases with the size of the module tables and that, despite the lower elevation angle, a higher energy yield is possible with concepts 3 and 4 . At the same time, however, the possible reverse side yield decreases by up to $4 \%$ compared to concept 1 .

Following the same procedure as mentioned above, where the investment costs and energy yields are used to calculate the specific costs, the end result shows that the specific costs of the first two variants are slightly more than for the comparison system.

Variants 3 and 4, on the other hand, have lower specific costs. Of the four different concepts, variant 4 , with an optimization of $0.84 \%$ compared to the reference system, at least in theory, represents the most economical PV system.

In the investigations, the bi-facial modules turned out to be the more economical variant for elevated PV ground-mounted systems. The additional yield of the bi-facial modules is high enough in the simulations to compensate for the additional costs and to achieve a positive benefit. Since it was not possible to determine whether the simulation software can realistically calculate the additional yield from bi-facial modules, it is nevertheless advisable to carry out a precise yield report in order to achieve a final result.

\section{Conclusions}

The bi-facial modules have not yet fully achieved the market breakthrough, but due to the ever increasing demands on solar modules, the trend is likely to continue to rise until the bifacial modules may have replaced the mono-facial modules for the most part on the market. Here, however, one can only assume speculation.

The increase in yield can be of great advantage, especially in regions such as in the African area, as the solar radiation is about twice as high as in the European area, whereby the profitability could probably be optimized again.

In addition to the pure increase in yield, the transparency and the longer shelf life due to the glass-glass construction speak for the use of bi-facial solar modules, as this opens up completely new applications for photovoltaics, in which conventional mono-facial modules could not be used efficiently. At the moment, the modules are mainly used as roof-integrated in greenhouses, in order to serve as both a power generator and a roof at the same time. The modules are also suitable for multi-purpose use for facades, balconies, noise barriers and carports. In addition, they can also be erected on flat roofs with the lightest possible foil as a substrate in order to increase the albedo value. In this case, the high reflection factor could achieve an additional energy yield on the back that clearly exceeds $5 \%$. For this reason, it is advantageous to examine the economic viability of bi-facial modules in other areas of application and to test them in practice. 


\section{References}

[1] Frontini F, Caccivio M, Renken C. Anwendung von bifazialen Solarmodulen Einsatzmöglichkeiten an Gebäuden, Dimensionierung der Anlagenkomponenten. EnergieSchweiz; 2019 August.

[2] Sperling P. Masterarbeit - Ertrags- und Kostenoptimierung von PVFreiflächenanlagen. 2016.

[3] Antony F, Dürschner C, Remmers KH. Photovoltaik für Profis: Verkauf, Planung und Montage von Solarstromanlagen. 2. vollständ. überarb. Edition. Solarpraxis; 2009.

[4] Alpha Solar \& Heizungstechnik GmbH. Halbzellenmodule - Der neue Trend bei den Modulherstellern 2019. http://docplayer.org/129827504- Halbzellenmodule-der-neue-trendbei-den-modulherstellern-2019.html. Accessed 2020 December 17.

[5] ET-SYSTEM. MPP-Tracking. https://www.etsystem.de/fileadmin/user upload/Applikationen Sondergeraete/MPPTracking HPSMP de.pdf. Accessed 2020 December 17.

[6] SMA Solar Technology AG. Wechselrichter: Leistungselektronik für eine saubere Energieversorgung. https://www.sma.de/partner/expertenwissen/wechselrichterleistungselektronikfuer-eine-saubere-energieversorgung.html

[7] Solibra System Montage Gmbh. Baubeschreibung für den geplanten Bau einer Photovoltaik-Freiflächenanlage auf der ehemaligen Kasernenanlage in Zerbst.

http://docplayer.org/62688876-Baubeschreibung-fuer-den-geplanten-bau-einer-photovoltaikfreiflaechenanlage-auf-der-ehemaligen-kasernenanlage-in-zerbst.html. 2017;

[8] Kutzer M, Fülle A, Jahnke A, Becker J, Hahn H, Wendt S, Neuhaus D, Witzig A, Kunath L, Stöckli U. Ertragssteigerung durch bi-faciale Modultechnologie.

https://www.velasolaris.com/wpcontent/uploads/2018/12/solarworld_otti_beitrag_final_1.pdf. 